\title{
A dabigatran iv. antidótumának, az idarucizumabnak első́ hazai alkalmazásai sürgős mútétek esetén
}

\author{
Driesz Lajos', Barabás Éva', Bodócs Ildikó', Szántó Zoltán', Hajdú Attila', \\ Herr György', Bencsik Gábor', Pál László2, Borbola József ${ }^{3}$
}

\author{
1JNKSZ Megyei Hetényi Géza Kórház-Rendelőintézet, Szolnok \\ ${ }^{2}$ Boehringer Ingelheim RCV GmbH \& Co KG, Magyarországi Fióktelepe, Budapest \\ ${ }^{3}$ Gottsegen György Országos Kardiológiai Intézet, Budapest
}

Levelezési cím: Dr. Borbola József, Gottsegen György Országos Kardiológiai Intézet, 1450 Budapest, Pf. 88

E-mail: borbola@kardio.hu

\begin{abstract}
Az új típusú, direkt orális antikoagulánsok közül jelenleg egyedül a direkt trombingátló dabigatran rendelkezik hatékony antidótummal. Az idarucizumab egy humanizált, monoklonális dabigatrant megkötő antitest-fragmentum, amely a gyógyszer szelektív véralvadásgátló hatását azonnal, tartósan, biztonságosan felfüggeszti. A szerzők a dabigatran iv. antidótuma, az idarucizumab első hazai alkalmazásait ismertetik sürgős mütéti indikációk esetén. Az első beteg (2016.05.23.) egy magas stroke-rizikójú, csökkent vesefunkciós 79 éves nöbeteg volt, aki nonvalvuláris paroxizmális pitvarfibrillációja miatt dabigatran (2×110 mg/nap) kezelést kapott, de gyulladt, köves epehólyag okozta hasi panaszai miatt akut hasi mütétre szorult. A második beteg szintén magas stroke-rizikójú, 72 éves férfi volt, aki nonvalvuláris permanens pitvarfibrillációja miatt dabigatran $(2 \times 150 \mathrm{mg} / \mathrm{nap})$ kezelésben részesült, de akut szeptikus jobb vállízületi gyulladása miatt emergenciális mütéti indikáció állt fenn. Mindkét betegnél a preoperatív hemosztázis-vizsgálat antikoaguláns hatásra utalt. Mindkét beteg a sürgető mütét elött dabigatran antidótumot (idarucizumab $2 \times 2,5 \mathrm{~g} / 50 \mathrm{ml}$ iv.) kapott, az iv. beadás kapcsán mellékhatást, szövődményt nem észleltek. Az urgens mütétek kapcsán kontrollálhatatlan vérzés nem volt. A betegek felgyógyulásuk után ismét dabitgatran kezelésre lettek visszaállítva.
\end{abstract}

Kulcsszavak: direkt orális antikoagulánsok, dabigatran, antidótum, idarucizumab

The first uses of iv. idarucizumab for dabigatran reversal in cases of urgent surgeries in Hungary

At present, the direct thrombin inhibitor dabigatran is the only one amongst the new direct anticoagulants which has an effective, specific reversal agent. The novel agent idarucizumab is a humanized, monoclonal antibody fragment binds to dabigatran within minutes thereby offers an opportunity to induce a safe, long-lasting reverse of the anticoagulant effects of dabigatran. The authors describe the first use of idarucizumab in the country in the cases of urgent surgery. The first case was a 79 years old female patient (23.05.2016) with non-valvular atrial fibrillation of high stroke risk-score and renal dysfunction who was taking dabigatran $(2 \times 110 \mathrm{mg} / \mathrm{day})$ when acute abdomen has been developed due to acute cholecystitis and cholecystolithiasis requiring emergency surgery. The second case was a 72 years old male patient with non-valvular atrial fibrillation of high stroke risk score who was on dabigatran therapy $(2 \times 150 \mathrm{mg} /$ day $)$, when an acute right shoulder joint inflammation had been developed requiring urgent surgery. The preoperative haemostasis investigation revealed anticoagulant influence in both patients. Both patient was received dabigatran antidote (idarucizumab $2 \times 2,5 \mathrm{~g}$ iv.) before the surgery, the antidote was feasible and safe without any side-effect. During the surgeries there was no any uncontrollable bleeding. Both patients received the dabigatran treatment back after their recovery.

Keywords: direct oral anticoagulants, dabigatran, antidote, idarucizumab 
Az elmúlt években négy új, direkt orális antikoaguláns (DOAC) gyógyszer (a direkt trombin-inhibitor dabigatran-etexilát (továbbiakban dabigatran) és a három szelektív Xa véralvadási faktor gátló (rivaroxaban, apixaban, majd az edoxaban) került hazai forgalomba (1, 2, 3, 4). Ezeknek a DOAC-szereknek az indikációja az iszkémiás stroke és a szisztémás embolizáció prevenciója nonvalvuláris pitvarfibrilláció (PF)-ban, egy vagy több kockázati tényezővel rendelkező felnőtt betegeknél. Továbbá a mélyvénás trombózis (deep vein thrombosis - DVT) és a pulmonalis embólia (PE) kezelése és az ismétlődő DVT és PE megelőzése felnőttekben a heparinok és a hagyományos K-vitamin-antagonista (KVA) gyógyszerek alternatívájaként $(5,6)$. A DOAC-szerek legalább olyan hatékonynak bizonyultak nagy klinikai vizsgálatokban, mint a KVA-gyógyszerek, ugyanakkor számos előnyük mellett kevesebb életveszélyes, súlyos vérzést okoznak, különösen az intracranialis haemorrhagiák tekintetében $(7,8)$. A DOAC-ot szedő betegeknél is előfordulhatnak azonban súlyos, életveszélyes, nem kontrollálható vérzések, többnyire gasztrointesztinális okok, traumatizáció miatt, vagy ritkábban gyógyszer-interakciók, túladagolások következtében. Ezen felül a DOAC-kezelést kapó betegeken nemritkán sürgősségi mütétek, azonnali invazív beavatkozások is szükségessé válhatnak. A RE-LY-vizsgálatban résztvevő 18113 betegnél 359 esetben (2\%) került sor sürgős mütétre (9). Ezért a DOAC-szerek bevezetése óta fontos orvosi igény, kívánalom volt ezeknek a gyors beavatkozást igénylő, sürgős helyzeteknek a megnyugtató megoldása, rendezése a véralvadásgátlás azonnali felfüggesztésével iv. antidótum adásával.

A DOAC-gyógyszerek közül elsőként a direkt trombin-inhibitor dabigatran antidótuma, az idarucizumab került kifejlesztésre, amely specifikusan kötődik a dabigatranhoz és semlegesíti annak antikoaguláns hatását $(10,11,12)$. Az idarucizumab egy humanizált, monoklonális, dabigatrant megkötő antitest-fragmens, amely a gyógyszer szelektív véralvadásgátló hatását azonnal, teljesen és tartósan felfüggeszti. Az antitest-fragmentum kizárólag a szabad dabigatran molekulákhoz és metabolitjaihoz kötődik, körülbelül 350-szer erősebb affinitással, mint amilyen a dabigatran-trombin kötődés. Az idarucizumab-dabigatran komplexet a nagy stabilitás jellemzi, mivel igen gyors a képződése, de extrém lassú a lebomlási képessége $(10,11,12)$. Laboratóriumi vizsgálatok igazolták, hogy az idarucizumab prompt helyreállítja, normalizálja a dabigatran által megnyúlt, említett paramétereket. Klinikai vizsgálatokban az antidótum iv. adása perceken belül, tartósan megszüntette a dabigatran antikoaguláns hatását egészséges önkéntesekben, majd dabigatrant szedő életveszélyes vérzéses vagy akut mütétre váró, sürgős invazív beavatkozásra szoruló betegek túlnyomó többségében. $A$ vizsgálatokban az antidótum iv. beadása után a szabad dabigatran plazma koncentrációja több mint 90\%-kal csökkent, ami antikoaguláns hatással nem járó vérszintet eredményezett (13).
$A z$ idarucizumabbal végzett RE-VERSE AD klinikai vizsgálat (14) megerősítette az ellenszer kedvező hatásosságát és biztonságosságát. Az eredmények alapján nemrégiben engedélyezték az első DOAC-gyógyszer, a dabigatran iv. antidótumának a forgalomba hozatalát először 2015 októberében az USA-ban, majd 2015 novemberében Európában is.

Jelen közlemény célja a dabigatran iv. antidótuma, az idarucizumab első hazai alkalmazásainak ismertetése nonvalvuláris pitvarfibrilláció miatt dabigatrant szedő, de társbetegségeik miatt akut mütétre szoruló két betegen.

\section{Esetismertetés}

\section{1. eset}

S.J.-né 79 éves nőbeteg $(160 \mathrm{~cm}, 55 \mathrm{~kg})$ 2016. 05. 23án került felvételre (11:40) a JNKSZ Megyei Hetényi Géza Kórház-Rendelőintézet Általános Sebészeti Osztályára akut has klinikai tüneteivel. Kórelőzményében hipertónia, COPD, kezelt hypothyreosis, nőgyógyászati mütét, pyelonephritis chronica, osteoporosis, diabetes mellitus (NIDDM2), spondylosis universalis, 2007 óta paroxizmális pitvarfibrillációs epizódok miatti kardiológiai kezelések szerepeltek. 2010-ben átmeneti icterusa hátterében epe aprókövességet állapítottak meg. 2012ben már észlelték anémiáját (Hgb: 88 G/l; Htk: 0,27 I/I), széklet Weber-vizsgálata negatív lett, hasi UH-vizsgálata során tumoros eltérést nem találtak. Echokardiográfiás vizsgálata (2015) jó szisztolés balkamra-funkciót, tág pitvarokat, balkamra-hipertrófiát véleményezett. A paroxizmális pitvarfibrillációs epizódok miatt alacsony dózisú amiodaron (másnaponta 200 mg/nap), valamint kezdetben acenocoumarol, majd dabigatran $(2 \times 110$ $\mathrm{mg} / \mathrm{nap})$ kezelésben részesült $\left(\mathrm{CHA}_{2} \mathrm{DS}_{2} \mathrm{VASc}\right.$ score: 6, HAS-BLED score: 4). 2016. februártól többször gyógykezelték belgyógyászati osztályokon, cholecystolithiasis, choledocholithiasis okozta panaszokkal. Emiatt ERCP, EST, kőextrakció, stentbehelyezés történt. Felvétele napján egy hete fennálló felhasi jobb oldali panaszok, aznap hajnal óta jelentősen fokozódó fájdalmak miatt az OMSZ szállította a Sebészeti Osztályra.

A felvételi vizsgálat, a laborleletek, a hasi UH-vizsgálat megerősítette az akut has diagnózisát. A preoperatív hemosztázis-vizsgálat (aktivált parciális tromboplasztin idő: 50,1 sec - kontroll: 25-43 sec - antikoaguláns hatására utalt. A dabigatran előző adagját felvételi napja előtti este vette be utoljára. Az aneszteziológiai konzílium dabigatran antagonista idarucizumab (Pradaxa ${ }^{\circledR}$, Boehringer Ingelheim $2 \times 2,5 \mathrm{~g} / 50 \mathrm{ml}$ iv. infúzió), valamint egy amp. K-vitamin és egy amp. Tranexam sav adását javasolta mütét előtt. Az antidótum beadása során mellékhatás, szövődmény nem volt. A hasi mútét (17:00) során gyulladt, hasüregbe perforált, vérző epehólyagot találtak. Cholecystectomia történt a hasüreg kimosásával és drenázzsal. $\mathrm{A}$ mütét során $2 \mathrm{E}$ csoportazonos vvt-masszát kapott. Az idarucizumab beadása után a 
parciális plazma tromboplasztin idő normalizálódott (1. táblázat). Átmeneti javulás után a 4. posztoperatív napon panaszai fokozódtak, belgyógyászati, laboratóriumi, hasi UH-kontroll után szepszis miatt reoperáció, exploratív laparatómia (05.27.) történt, amely zajló akut, diffúz peritonitis képet, nem friss vérzést talált. Lavage, drenázs történt, majd a beteg az ITO-ra került.

Intenzív ápolása, sebkezelése mellett gépi lélegeztetésben, analgoszedációban részesült, antitrombotikus (nadroparin $2 \times 0,4 \mathrm{ml} \mathrm{sc}$.), antiulceratív kezelést kapott, célzott antibiotikum-terápiában részesült. Állapota fokozatosan javult, visszahelyezésre került a Sebészeti Osztályra. Gyógyulását kialakult pneumóniája átmenetileg késleltette, amely azután antibiotikum-kezelésre szanálódott. Fokozatos mobilizáció kapcsán állapota stabilizálódott, vesefunkciója javult (GFR: $48 \mathrm{ml} /$ perc). A kórházi szakban kapott nadroparin kezelésröl visszaállították a dabigatran stroke prevencióra $(2 \times 110 \mathrm{mg} /$ nap), később pedig otthonába bocsátották.

\section{2. eset}

T.M. 72 éves férfi $(176 \mathrm{~cm}, 85 \mathrm{~kg}), 2016.07 .18$-án került felvételre (17:55) a JNKSZ Megyei Hetényi Géza Kórház-Rendelőintézet Traumatológiai Osztályára jobb vállízületi akut purulens gyulladás tüneteivel. Kórelőzményében hipertónia, korábbi stroke, pitvarfibrilláció miatti dabigatran $\left(2 \times 150 \mathrm{mg} /\right.$ nap) kezelés $\left(\mathrm{CHA}_{2} \mathrm{DS}_{2} \mathrm{VASc}\right.$ score: 4; HAS-BLED score: 3) szerepeltek. A dabigatrant felvétele napján reggel vette be utoljára. $A$ jobb váll CT-vizsgálata, a labormarkerek megerősítették a felvételi diagnózist. A sürgős hemosztázis-vizsgálat (aktivált plazma tromboplasztin idő: $52,2 \mathrm{sec}$ [kontroll: $34,5 \mathrm{sec}$ ]) antikoaguláns hatásra utalt. A sürgős mütéti indikáció miatt a beteg preoperatíve dabigatran antidótumot, idarucizumabot (Praxbind ${ }^{\circledR}$, Boehringer-Ingelheim, 2×2,5 $\mathrm{g} / 50 \mathrm{ml}$ iv.) kapott. Mellékhatás, szövődmény nem volt. A mütétre aznap este 20:00 órakor került sor, a reggeli dabigatran bevétele után kb. 12 órával. A vesefunkció normális volt (GFR: $71 \mathrm{ml} / \mathrm{perc}$ ). A mütét során (vállízületi feltárás, debridement, öblítő drenázs felhelyezés) számottevő vérzés nem volt. (Mütét előtt Hgb: 140,0 g/l; Htk: 0,42 l//; műtét után Hgb: 133,0 g/l, Htk: 0,39 I/l). A beteg célzott, további antibiotikum-kezelésre megygyógyult. A kórházi szakban alacsony molekulasúlyú heparint kapott. Hazabocsátása során (2016.07.26.) a dabigatran kezelésre visszaállították.

\section{Megbeszélés}

A dabigatran antidótumának (idarucizumab) első hazai alkalmazására - a DOAC-gyógyszerek közül elsőként - egy nonvalvuláris, paroxizmális PF-epizódok (magas $\mathrm{CHA}_{2} \mathrm{DS}_{2} \mathrm{VASc}$ score: 6) miatt dabigatran kezelésben ( $2 \times 110 \mathrm{mg} / \mathrm{nap})$ részesülő idős nőbeteg esetében került sor, akinek epekövessége kapcsán kialakult akut hasi tünetei miatt emergenciális sebészeti mütétre volt szüksége. A betegnek az aneszteziológiai konzílium mütét előtt idarucizumab adását $(2 \times 2,5 \mathrm{~g} / 50 \mathrm{ml}$ iv. $)$ írta elö, amelyet a beteg szövődménymentesen megkapott a tervezett mútéte előtt kb. 2 órával, az utolsó dabigatran adag bevétele után 20 órával. A hasi mútét során vérző, a hasüregbe perforált gyulladt epehólyagot találtak a sebészek, csillapíthatatlan vérzés nem volt. A beteg mütét elött $1 \mathrm{amp}$. iv. K-vitamint és $1 \mathrm{amp}$. Tranexamot is kapott. A mütét után $2 \mathrm{E}$ vvt-massza adására is sor került az eleve ismerten anémiás idős nőbetegnél. A beteg néhány kiemelt laboratóriumi értékének a kontrollhoz képesti változását az idarucizumab javasolt dózisának iv. beadása előtt, majd a hasi mütét után az 1. táblázatban tüntettük fel. Az idarucizumab beadása előtti hemostátus vizsgálata fokozott antikoaguláns hatásra (emelkedett APTI-érték) utalt. Az 1. táblázatból az is kitủnik, hogy az antidótum beadása után, másnap reggelre az APTI-érték normalizálódott, másrészt pedig látható, hogy a beteg mütét előtti vesefunkciója jelentősen

1. TÁBLÁZAT. Néhány kiemelt laboratóriumi paraméter változása az iv. idarucizumab $(2 \times 2,5 \mathrm{~g} / 50 \mathrm{ml}$ iv.) beadása előttt és után

\begin{tabular}{|l|c|c|c|}
\hline Vérvétele ideje & $\begin{array}{c}\text { Idarucizumab beadása elött } \\
\text { 05.23. 11:57 }\end{array}$ & $\begin{array}{c}\text { Idarucizumab beadása után } \\
\mathbf{0 5 . 2 4 . ~ 0 5 : 3 5 ~}\end{array}$ & $\begin{array}{c}\text { Laboratóriumi paraméte- } \\
\text { rek normál értékei }\end{array}$ \\
\hline Hemoglobin & 93,70 & 90,10 & $120-160 \mathrm{~g} / \mathrm{l}$ \\
\hline Hematokrit & 0,28 & 0,26 & $0,36-0,46 \mathrm{I} / \mathrm{l}$ \\
\hline Fehérvérsejtszám & 19,70 & 25,00 & $4,0-10,0 \mathrm{G} / \mathrm{l}$ \\
\hline Trombocitaszám & 464,00 & 361,00 & $150,0-400,0 \mathrm{G} / \mathrm{l}$ \\
\hline INR & 1,88 & 1,87 & $0,9-1,3$ \\
\hline Protrombinidő & 22,00 & 22,00 & $10-17 \mathrm{sec}$ \\
\hline APTI & 50,1 & 42,2 & $25-43 \mathrm{sec}$ \\
\hline Karbamid & 17,7 & 17,1 & $2,5-7,5 \mathrm{mmol} / \mathrm{l}$ \\
\hline Kreatinin & 251,0 & 205,0 & $40-88 \mu \mathrm{mol} / \mathrm{l}$ \\
\hline GFR & 15,0 & 19,0 & $>90 \mathrm{ml} / \mathrm{min}$ \\
\hline CRP & 149,5 & 200,3 & $<5,0 \mathrm{mg} / \mathrm{l}$ \\
\hline
\end{tabular}

(A dabigatran utolsó adagjának bevétele: 2016.05.22 [19-20 óra között]. Az idarucizumab beadása 2016.05.23. 15:00 A hasi mütét kezdete 17:00. A beteg a hasi mütét után $2 \mathrm{E}$ vvt-massza transzfúziót kapott.) 
csökkent volt. Ez utóbbi a föként renalis clearance-ü dabigatran eliminációját jelentősen megnyújtja (becsült felezési idő $\geq 20$ óra), plazmakoncentrációját megnöveli. Ebben az esetben, antidótum adása nélkül, a magas operatív vérzési rizikó miatt $\geq 96$ órás dabigatran leállítás javasolt elektív invazív vagy sebészeti beavatkozás előtt $(6,15)$. Esetünkben az akut has miatt a hasi mütét sürgős volt, így feltétlenül indokolt volt az antidótum, az idarucizumab beadása. Az említetteken kívül a vérzési kockázatot tovább növelte az otthoni NSAID szedése, valamint a máffunkció-zavarra utalható magasabb INR-érték $(1,88)$ is. A beteg HAS-BLED pontszáma (4) is fokozott vérzéses rizikót jelzett (7).

A második beteg esetében akut jobb vállízületi purulens gyulladás miatt halaszthatatlan mütéti kezelésre volt szükség. Az antidótum beadása után a mütét elvégezhetővé vált, számottevő vérzés nem volt, a vérkép közel változatlan maradt a beavatkozás után. A dabigatran eliminációját befolyásoló vesefunkció ebben az esetben normális volt.

A rutin, jelenlegi gyakorlatban sajnos nem áll rendelkezésre megbízható módszer, paraméter a dabigatrannal elért alvadásgátlás intenzitásának a pontos megítélésére a dabigatran vérszinten kívül. Az APTI értéke csak megközelítőleg jelzi az antikoaguláns hatást, a vizsgálatok nem standardizáltak, az eredményeket pedig körültekintéssel kell értékelni (10). Hasznos lehet a trombinidő ( $\mathrm{TI})$, a higított trombinidő ( $\mathrm{h}-\mathrm{TI}$ ) és az ecarin alvadási idő (ECI) meghatározása is, de ezek sem standardizáltak, az eredményeket szintén körültekintéssel kell fogadni $(10,16)$. Az említetteken kívül az antikoaguláns paraméterek nemcsak a mintavétel, hanem az utolsó dabigatran dózis bevételének az időpontjától is függenek. A dabigatran bevételét követően 2 órával levett vérminta (csúcskoncentrációt jelzi), más, magasabb értéket ad minden alvadási paraméter vizsgálata esetén, mint az ugyanazon adag bevételét 10-16 órával követő vérminta (mélyponti szint) kapcsán (16). Az első esetünkben az első vérminta vétele az előző esti dabigatran bevétel után kb. 16 órával később történt, amely a mélyponti szintnek felel meg. A második betegnél a mütétre a reggeli dabigatran bevétel után kb. 12 órával került sor, az ún. mélyponti dabigatran vérszinthez közeli állapotban. Az eleve anémiás, idős nőbeteg esetében a gyulladt, hasüregbe perforált, vérző epehólyagmütéte kapcsán az antidótumnak is köszönhetően kontrollálhatatlan vérzés nem volt, de a beteg a mütét után transzfúzióra szorult.

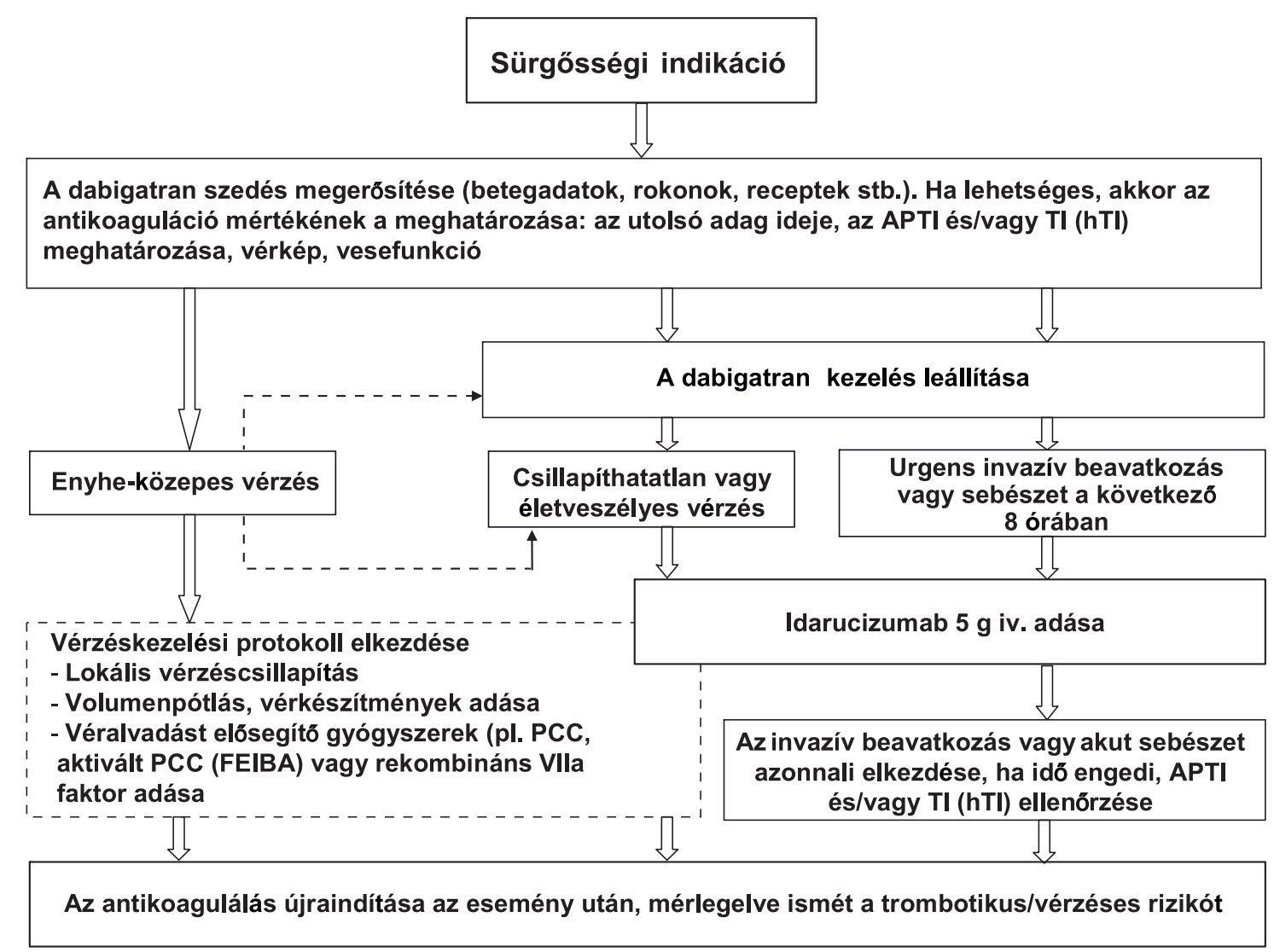

1. ÁBRA. A dabigatran antidótum idarucizumab alkalmazása sürgős ellátást igénylő esetekben. A dabigatrannal kezelt betegek iv. idarucizumab adásának javasolt algoritmusa. (Két 50 ml-es idarucizumab iv. adása infúzióban vagy bólus injekcióban (mindegyik 2,5 g-ot tartalmaz) az oldat azonnali használatra kész. Ha ritkán a dabigatran antikoaguláció fennmaradna, és a vérzés folytatódna, akkor egy második 5 g-os adag adása megfontolandó. APTI: aktivált parciális tromboplasztin idő, PCC: protrombin komplex koncentrátum, aktivált PCC (FEIBA), TI: trombinidő, hTl: higított trombinidő) 
2. TÁBLÁZAT. A dabigatran specifikus antidótuma, az idarucizumab néhány fontos tulajdonsága és alkalmazása

\begin{tabular}{|c|c|}
\hline \multicolumn{2}{|c|}{ Idarucizumab (Praxbind ${ }^{\circledR}$ ) } \\
\hline Hatás & $\begin{array}{l}\text { A dabigatran antikoaguláns hatásának } \\
\text { azonnali, teljes és tartós felfüggesztése }\end{array}$ \\
\hline \multirow[t]{3}{*}{ Biztonságosság } & Nincsen protrombotikus hatása \\
\hline & $\begin{array}{l}\text { Immunreakció generálási lehetőség } \\
\text { minimális }\end{array}$ \\
\hline & Nemkívánatos eseményt nem figyeltek meg \\
\hline \multirow[t]{4}{*}{ Adagolás } & $\begin{array}{l}5 \mathrm{~g}(2 \mathrm{db} 2,5 \mathrm{~g} / 50 \mathrm{ml} \text {-es ampulla) gyors iv. } \\
\text { infúzióban vagy bólusban }\end{array}$ \\
\hline & Azonnali használatra kész oldatban \\
\hline & $\begin{array}{l}\text { Azonos dózis minden beteg számára, } \\
\text { dózismódosítás nem szükséges }\end{array}$ \\
\hline & Más iv. gyógyszerekkel elegyíteni tilos \\
\hline \multirow[t]{2}{*}{ Féléletidő } & Terminális féléletidő: 10,3 óra \\
\hline & $\begin{array}{l}\text { A dabigatran az idarucizumab beadása } \\
\text { után } 24 \text { óra múlva ismét alkalmazható }\end{array}$ \\
\hline Kiürülés & Föleg a vesén keresztül ürül \\
\hline \multirow[t]{2}{*}{$\begin{array}{l}\text { Gyógyszer- } \\
\text { interakciók }\end{array}$} & $\begin{array}{l}\text { Nem lép más gyógyszerekkel kölcsönha- } \\
\text { tásba }\end{array}$ \\
\hline & $\begin{array}{l}\text { Egyéb antitrombotikus kezelés } \\
\text { (pl. LM WH) a szer beadása után azonnal } \\
\text { alkalmazható }\end{array}$ \\
\hline $\begin{array}{l}\text { Más támogató ke- } \\
\text { zelés lehetősége }\end{array}$ & $\begin{array}{l}\text { A szer igény szerint alkalmazható egyéb } \\
\text { támogató jellegü kezelésekkel együtt }\end{array}$ \\
\hline
\end{tabular}

Az idarucizumab a direkt trombininhibitor dabigatran specifikus ellenszere, antidótuma, amely sürgősségi helyzetekben felnőtteknél alkalmazható, amikor a dabigatran hatásának a gyors felfüggesztésére van szükség sürgős mütétek/beavatkozások vagy életveszélyes, csillapíthatatlan vérzések esetén. A dabigatránnal kezelt betegek idarucizumab adásának javasolt algoritmusa az 1. ábrán látható. Klinikai vizsgálatokban (RE-VERSE AD) az idarucizumab iv. adása perceken belül, tartósan felfüggesztette a dabigatran antikoaguláns hatását. $\mathrm{Az}$ antikoaguláns hatás felfüggesztése után a betegek 92\%-ánál normál intraoperatív hemosztázist értek el, protrombotikus, prokoaguláns hatást nem tapasztaltak $(13,14,17)$. Az antidótum adása kontraindikált idarucizumab allergia, örökletes fruktóz-intolerancia (szorbitot tartalmaz a gyógyszer), terhesség vagy szoptatás esetén. Az idarucizumab néhány fontos tulajdonságát és klinikai alkalmazását a következő 2. táblázat foglalja össze.

Nemrégen számoltak be dabigatrannal kezelt non-valvuláris PF-ben elszenvedett iszkémiás stroke sikeres szisztémás trombolitikus kezeléséről 5 perccel az iv. antidótum beadása után $(18,19)$. Ugyancsak leírták (20) az iv. antidótum sikeres alkalmazását túladagolás esetén egy 68 éves nőbetegen, aki 125 kapszula da- bigatrant nyelt le. Nála az eredetileg tervezett hemodialízisre sem volt szükség (a dabigatran az egyetlen dializálható DOAC-készítmény).

\section{Következtetések}

Első tapasztalataink szerint a DOAC-szerek közül a dabigatran kezelés egyedülálló biztonságot nyújt azáltal, hogy a speciális antidótuma, az idarucizumab is a kezelőorvos rendelkezésére áll vészhelyzetekben, amely eseteinkben is lehetővé tette a sürgős mütétek biztonságos elvégzését.

\section{Irodalom}

1. Conolly SJ, Ezekowitz MD, Yusuf S, et al. Dabigatran versus warfarin in patients with atrial fibrillation. N Engl J Med 2009; 361: 1139-1152. https://doi.org/10.1056/NEJMoa0905561

2. Patel MR, Mahaffey KW, Garg J, et al. Rivaroxaban versus warfarin in nonvalvular atrial fibrillation. N Engl J Med 2011; 365: 883-891. https://doi.org/10.1056/NEJMoa1009638

3. Conolly SJ, Eikelboom J, Joyner D, et al. Apixaban in patients with atrial fibrillation. N Engl J Med 2011; 364: 806-817.

https://doi.org/10.1056/NEJMoa1007432

4. Ruff CT, Gingliano RP, Antman EM, et al. Evaluation of the novel Xa inhibitor edoxaban compared with warfarin in patients with atrial fibrillation. Am Heart J 2010; 160: 635-641.

https://doi.org/10.1016/j.ahj.2010.06.042

5. Urooj F, Kulkarni A, Stapleton D, et al. New oral anticoagulants in nonvalvular atrial fibril-lation. Clin Cardiol 2016; 39: 739-746. https://doi.org/10.1002/clc.22582

6. Narisimha $D$, Curtis AB. Anticoagulation for atrial fibrillation in the elderly. Arch Med 2015; 7: 1-12.

7. Heidbuchel H, Verhamme $P$, Allings $M$, et al. European Heart Rhyt$\mathrm{hm}$ Association Practical Guide on the use of new oral anticoagulants in patients with non-valvular atrial fibrillation. Europace 2013; 15: 625-651.

https://doi.org/10.1093/europace/eut083.

8. Graham DJ, Reichman ME, Wernecke M, et al. Stroke, bleeding, and mortality risks in elderly Medicare beneficiaries treated with dabigatran or rivaroxaban for nonvalvular atrial fibrillation. JAMA Intern Med 2016; 176(11): 1662-1671. https://doi.org/10.1001/jamainternmed.2016.5954

9. Healy JS, Eikelboom J, Doukatis J, et al. Periprocedural bleeding and thromboembolic events with dabigatran compared with warfarin. Circulation 2012; 126: 343-348.

https://doi.org/10.1161/CIRCULATIONAHA.111.090464

10. VanRyn J, Strangier J, Haertterm S, et al. Dabigatran etexilate - a novel, reversible, oral direct thrombin hinhibitor: interpretation of coagulation assays and reversal of anticoagulant activity. Thromb Haemost 2012; 103: 1116-1127. https://doi.org/10.1160/TH09-110758

11. Pollack CV, Reilly PA, Eikelboom I, et al. Idarucizumab for dabigatran reversal. New Engl J Med 2015; 373: 511-520.

https://doi.org/10.1056/NEJMoa1502000

12. Eikelboom JW, Quinlan DJ, Ryn J, et al. Idarucizumab the antidote for reversal of dabigatran. Circulation 2015; 132(25): 2412-2422. https://doi.org/10.1161/CIRCULATIONAHA.115.019628

13. Glund S, Stangier J, Schmohl, M, et al. Safety, tolerability and 
efficacy of idarucizumab for the reversal of the anticoagulant effect of dabigatran in healthy male volunteers: a random-ised, placebo-controlled, double-blind phase-1 trial. Lancet 2015; 386: 680-690. https://doi.org/10.1016/S0140-6736(15)60732-2

14. Pollack CV, Reilly PA, Bernstein R, et al. Design and rationale for RE-VERSE AD: a phase 3 study of idarucizumab, a specific reversal agent for dabigatran. Thromb Haemost 2015; 114: 1736-1746. https://doi.org/10.1160/TH15-03-0192

15. Graham DJ, Reichmann ME, Wernecke M, et al. Cardiovascular, bleeding, and mortality risk in elderly Medicare patients treated with dabigatran or warfarin for nonvalvular atrial fibrillation. Circulation 2015; 131(2): 157-164. https://doi.org/10.1160/TH15-03-0192

16. Pradaxa ${ }^{\circledR}$ (dabigatran etexilát) prescribing guideline (Felírói út- mutató). Boehringer Ingel-heim 2015.

17. Praxbind ${ }^{\circledR}$ Summary of the product (alkalmazási előírás). Boehringer-Ingelheim 2016

18. Schäfer N, Müller A, Wüllner U. Systemic thrombolysis for ischaemic stroke after antagonizing dabigatran with idarucizumab - A case report. J Stroke Cerebrovasc Dis 2016; 25(8): 126-127.

https://doi.org/10.1016/j.jstrokecerebrovasdis.2016.05.006

19. Berrouschot I, Stoll A, Hogh T, et al. Intravenous thrombolysis with recombinant tissue-type plasminogen activator in a stroke patient receiving dabigatran anticoagulant after antagonization with idarucizumab. Stroke 2016; 47(7): 1936-1938

https://doi.org/10.1161/STROKEAHA.116.013550

20. Peetermans $M$, Pollack $C$, Reilly $P$, et al. Idarucizumab for dabigatran overdose. Clin Toxicol 2016; 54(8): 644-646

https://doi.org/10.1080/15563650.2016.1187737 